\title{
嗜好度間相関を検討するための シェッフェ型一対比較モデル
}

\author{
岩間 徳兼 ${ }^{2,3}$ 豊田 秀樹 早稲田大学
}

\section{Scheffé-type paired comparison models for examining correlations between individual preferences for alternatives}

\author{
Norikazu Iwama and Hideki Toyoda (Waseda University)
}

\begin{abstract}
It is difficult to estimate and examine correlations between individual preferences for alternatives using the present Scheffé-type paired comparison models. In this paper, we propose two models that address individual preferences for alternatives. One is a simple model that makes it possible to estimate correlations between individual preferences. The other is an improved model that makes it possible to extract independent components from those correlations. Paired comparison data were collected in a survey about preferences for several new product names. Analysis of this data shows that the proposed models enabled the estimation not only of average preferences for alternatives, but also correlations between individual preferences and loading matrices for independent components. The effectiveness of the proposed methods was confirmed by the interpretations of those estimates.
\end{abstract}

Key words: paired comparison, preference correlations, structural equation modeling, independent components, third-order moments.

The Japanese Journal of Psychology

2011, Vol. 82, No. 5, pp. 442-449

複数の対象をある心理尺度上に位置づけるために利 用される方法の一つに一対比較法がある。一対比較法 は複数の対象の中から 2 個ずつを選んで比較対を作 り，それらに対する評価をもとに各対象の心理尺度值 を得る方法であり，態度，価值，嗜好度などの心理量 を測定する目的で用いられる。本論文においては心理 量として嗜好度を扱い, 一対比較の代表的モデルの一 つであるシェッフェモデル（Scheffé, 1952）に焦点を 当てる。まずは，本論文で扱う問題を具体的にするた め, 多重評価状況下に扔けるシェッフェ型の一対比較 モデルについて説明する。

シェッフェの一対比較モデルの原法ではひとりの評

\footnotetext{
Corresponding concerning this article should be sent to: Norikazu Iwama, Graduate School of Humanities and Social Sciences, Waseda University, Toyama, Shinjuku-ku, Tokyo 162-8644, Japan (e-mail: n.iwama0119@aoni.waseda.jp)

1 本研究の一部は, 日本学術振興会の科学研究費補助金（特 別研究員奨励費）を受けて行われた。

2 日本学術振興会特別研究員

3 本研究にあたり調查にご協力下さった多くの方々に対して 深謝いたします。
}

価者は対象に関する提示順序を考慮した比較対のうち 一つのみを評価することになっているが, ここではひ とりの評価者が対象に関する提示順序を考慮した全て の比較対を評価する場面を考える。そのような多重評 価の状況下におけるシェッフェ型の一対比較モデルは

$$
\begin{aligned}
x_{i j k} & =f_{i k}-f_{j k}+\gamma_{i j}+\delta_{k}+e_{i j k} \\
& =\left(\alpha_{i}+\beta_{i k}\right)-\left(\alpha_{j}+\beta_{j k}\right)+\gamma_{i j}+\delta_{k}+e_{i j k}
\end{aligned}
$$

のように表現される（佐藤, 1985)。(1)式の $x_{i j k}$ は評 価者 $k$ が対象 $i$ と対象 $j$ をこの順で一対比較した際に 対象 $i$ 対象 $j$ よりどの程度好むかについての評価值 を表す。評価值はモデル上では連続変数だが, 実際に は原点を 0 とした $5 ， 7 ， 9$ 件法などにより多值の形で 得られる。そして, $f_{i k}$ と $f_{j k}$ はそれぞれ対象 $i$ と対象 $j$ に対する評価者 $k$ の嗜好度である。(2)式に示される ように $f_{i k}$ は対象 $i$ に対する平均的嗜好度 $\alpha_{i}$ と, 嗜好 度に関する, 評価者 $k$ に固有の平均的嗜好度からの 偏差，つまり個人差 $\beta_{i k}$ の和から成る。平均的嗜好度 には $\sum_{i=1}^{n} \alpha_{i}=0$ という制約が置かれる場合が多い。こ の平均的嗜好度の值によって, 各対象に対する嗜好の 程度を評価することができる。また，個人差には， $\sum_{k=1}^{r} \beta_{i k}=0$ という制約が置かれる。ただし， $n$ は対象 
の数, $r$ は評価者の数を表す。次に $\gamma_{i j}$ は対象 $i$ と対象 $j$ の順序付き比較における対象の組み合わせ効果であ り，これには $\sum_{i=1}^{n} \gamma_{i j}=\sum_{j=1}^{n} \gamma_{i j}=0, \gamma_{i j}=-\gamma_{j i}$ という制約 が置かれる。そして， $\delta_{k}$ は評価者ごとに定義される， 比較の際の順序効果である。最後に, $e_{i j k}$ は対象 $i$ と 対象 $j$ の順序付き比較での評価值に含まれる誤差を表 している。

シェッフェの一対比較モデルは分散分析モデルと数 理的に同等であり，分散分析を行うことも可能な構造 方程式モデリング（Structural Equation Modeling：以 下 SEM とする）の枠組みから多重評価状況下のシェ ッフェの一対比較デー夕を解析する手法が提案されて きた（豊田・室橋・尾崎・芳賀， 2004; 豊田・尾崎 · 室橋・芳賀，2004）。SEM を利用して分析する主な利 点としては, 各対象の尺度值を表す平均的嗜好度の推 定值やその標準誤差を容易に求められること, 対象に 対する好みの散らばりについて考察できること，個人 差を因子得点として推定できることが挙げられる。な お, シェッフェ型の一対比較における個人差の検討の 有効性については，野澤・飯田・椿 - 芳賀 ·鎗田・吉 澤（1995）においても示唆されている。

ここで以降の説明のため，モデルを行列形式で再表 現することを考える。ただし，簡単なために組み合わ せ効果を省略することとする。さらに，評価時におけ る判断の往復を許し, 順序効果の項も考慮しない状況 を想定する。そのとき，評価值に関して $x_{i j k}=-x_{j i k}$ の 関係が成り立つとすることにより,$i<j$ である $x_{i j k}$ の みが得られていると考えることができる。すると $n$ 個 の対象に関する $m=n(n-1) / 2$ 個の評価値を

$$
\boldsymbol{x}_{k}=\boldsymbol{A} \boldsymbol{f}_{k}+\boldsymbol{e}_{k}
$$

と表現できる。 $\boldsymbol{A}$ は $m \times n$ 計画行列, $\boldsymbol{x}_{k}, \boldsymbol{f}_{k}, \boldsymbol{e}_{k}$ はそれ ぞれ評価者 $k$ についての, $m \times 1$ 評価值ベクトル, $n$ $\times 1$ 嗜好度べクトル, $m \times 1$ 誤差ベクトルである。

対象が四つの場合を例にとると $n=4, m=6$ となり， (3)式に打ける $\boldsymbol{x}_{k}=\left(x_{12 k}, x_{13 k}, x_{14 k}, x_{23 k}, x_{24 k}, x_{34 k}\right)^{\prime}$ は, 評価者 $k$ の各比較対における評価值が要素とし て含まれる $6 \times 1$ ベクトルとなる。なお， $x_{12 k}$ の添え 字 12 は対象 1 と対象 2 の比較であることを示してい る。また, $\boldsymbol{f}_{k}=\left(f_{1 k}, f_{2 k}, f_{3 k}, f_{4 k}\right)^{\prime}$ は $4 \times 1$ ベクトルで あり, 評価者 $k$ の各対象への嗜好度が要素として含 まれる。そして, $\boldsymbol{e}_{k}=\left(e_{12 k}, e_{13 k}, e_{14 k}, e_{23 k}, e_{24 k}, e_{34 k}\right)^{\prime}$ は $6 \times 1$ ベクトルであり, 評価者 $k$ の各比較対の評価 における誤差が要素として含まれる。最後に， $6 \times 4$ 行列 $\boldsymbol{A}$ は一対比較モデルを表現するための計画行列 であり，具体的には以下のようになる。

$$
\boldsymbol{A}=\left[\begin{array}{rrrrrr}
1 & 1 & 1 & 0 & 0 & 0 \\
-1 & 0 & 0 & 1 & 1 & 0 \\
0 & -1 & 0 & -1 & 0 & 1 \\
0 & 0 & -1 & 0 & -1 & -1
\end{array}\right]^{\prime}
$$

以降では, 確率ベクトル $\boldsymbol{x}, \boldsymbol{f}, \boldsymbol{e}$ の実現值として評 価者 $k$ に関するべクトル $\boldsymbol{x}_{k}, \boldsymbol{f}_{k}, \boldsymbol{e}_{k}$ が得られていると 捉え直し，(3)式から $k$ を省略した確率べクトルによ る表現

$$
\boldsymbol{x}=\boldsymbol{A f}+\boldsymbol{e}
$$

で議論を進める。このとき, $\mathrm{E}[\boldsymbol{e}]=\mathbf{0}$, および $\boldsymbol{f}$ と $\boldsymbol{e}$ は独立であると仮定すると平均構造と共分散構造は

$$
\begin{aligned}
& \mu_{x}=\boldsymbol{A} \boldsymbol{\alpha} \\
& \boldsymbol{\Sigma}_{x}=\boldsymbol{A} \boldsymbol{\Sigma}_{f} \boldsymbol{A}^{\prime}+\boldsymbol{\Sigma}_{e}
\end{aligned}
$$

となる。ここで, $\mathrm{E}[f]=\alpha$ は各対象の平均的嗜好度を 表す $n \times 1$ 母数べクトルであり, $\alpha^{\prime} \mathbf{1}_{n}=0$ を満たすと 仮定される。対象が四つの場合には $\left(\alpha_{1}, \alpha_{2}, \alpha_{3}, \alpha_{4}\right)^{\prime}$ となる。そして, $\boldsymbol{\beta}=\boldsymbol{f}-\boldsymbol{\alpha}$ によって喏好度における個 人差が表現される。また， $\boldsymbol{\Sigma}_{e}$ は $\boldsymbol{e}$ の $m \times m$ 共分散行 列であり，対角行列であるという仮定が置かれる。な お，シェッフェの原法では $e_{i j} に は$ 添え字にかかわら ず等分散が仮定されており, その場合 $\boldsymbol{\Sigma}_{e}$ の対角要素 はすべて等しくなる。

シェッフェの一対比較モデルをSEMによって分析 するこれまでの手法では, 嗜好度 $\boldsymbol{f}$ の間の相関につい ては，共分散行列 $\boldsymbol{\Sigma}_{f}$ が対角行列であると仮定が置か れていた（豊田・尾崎他，2004）。つまり, 各対象の 嗜好度は無相関であるとされていた。これは, 喏好度 間共分散行列 $\boldsymbol{\Sigma}_{f}$ と $\boldsymbol{\Sigma}_{f}+\boldsymbol{d} \mathbf{1}^{\prime}+\mathbf{1} \boldsymbol{d}^{\prime}$ との識別が不可能で あるという根本的な問題を一対比較モデルが内包する ことに由来した (Arbuckle \& Nugent, 1973; Tsai, 2000, 2003），モデル識別を目的とする仮定であり，実質科 学的観点に基づいているわけではない。似た特徴を有 する対象があれば，同一個人のそれらに対する喏好は 似ており，喏好度の間に相関が生じるはずであるか ら, 現実的にみても共分散が 0 というのは非常に強い 仮定であり，そこに存在する有効な情報を無視してし まう危険性が強い。

また， $\boldsymbol{\Sigma}_{f}$ の識別性を考慮すると，嗜好度間共分散 を推定するための方法として, 各対象に関する喏好度 の分散を 1 などの固定值に制約して残りの共分散要素 を推定する方法や一つの対象に関して分散を 1 などの 固定值に，その対象とそれ以外の対象との嗜好度間共 分散を 0 に制約して残りの分散共分散要素を推定する 方法が考えられる。しかし前者については，多くの人 が同じような好みを示す個人差の小さな対象と好みが 大きく分かれ易い個人差の大きな対象があるのが普通 であるから，全対象についての嗜好度の分散が等しい という仮定はかなり強いといえる。また，後者に関し ては，対角行列の仮定の場合ほどではないにしろ，共 分散に関する 0 の仮定と情報の一部の欠落という問題 がある。

上記のように，これまで提案されてきたシェッフェ の一対比較データの分析方法では対象に対する各個人 の嗜好度間の相関関係について適切に検討できる方法 
はほとんどなく, 従来の分析方法では嗜好度間相関の 情報は積極的に利用されてこなかった。当然のことな がらその情報は非常に有益であり，適切に知ることが できれば対象に対する好みの関係性やその背後にある 要因について深く検討することが可能となる。そこ で，本論文では多重評価状況下でのシェッフェの一対 比較に抢いて対象の喏好度間相関を適切に検討するこ とを目的とした，SEM の枠組みによる有効な方法を 二つ提案する。

一つ目は，嗜好度に関する自然な仮定を導入するこ とにより共分散構造分析で嗜好度間相関行列の推定を 可能とする方法であり，その方法では上で述べた恣意 的な固定值の問題は解決され, 情報の欠落も生じるこ とはない。

二つ目は, 嗜好度間の関係に基づいてそれらの背後 に想定される独立成分の抽出をも可能とする， 3 次積 率を用いた SEM による分析方法である。これは一つ 目の方法を発展させた方法であり, 固定值を用いる必 要や情報の欠落が生じないばかりか, 3 次積率の利用 によって成分抽出に扔ける回転の不定性を解決してい るという特長を有している。

これらの手法では, SEM の観点から分析する利点 も十分に生かされており，対象に対する喏好度間の相 関関係について適切かつ詳しく検討することが可能と なる。

\section{モ デル}

\section{嗜好度間相関推定モデル}

モデル表現と母数推定 まず，対象の嗜好度間共分 散行列を推定するにあたり

$$
\boldsymbol{f}=\boldsymbol{\Lambda} \boldsymbol{f}_{-1}
$$

という喏好度に関するイプサティブスコアの制約を設 ける。ここで, $\boldsymbol{f}_{-1}$ は $\boldsymbol{f}$ から任意の一つの要素を除い た $(n-1) \times 1$ ベクトルであり, 本論文では最後の要 素を除いたベクトルとして定める。また， $\Lambda$ はイプサ ティブスコアの制約を表現するための $n \times(n-1)$ 行 列である。

もともと喏好度は構成概念であるから, 個人内での 選好度の平均が 0 という基準を定めることには問題が ない。また, 相対的な比較判断に関する観測変数が,

同じく相対的な嗜好度から生じているというのも自然 な考えである。さらに，(8)式を実現值レベルで考える と $\sum_{i=1}^{n} \alpha_{i}=0, \sum_{i=1}^{n} \beta_{i k}=\sum_{k=1}^{r} \beta_{i k}=0$ を表現していること に相当する。この仮定はシェッフェの原法を拡張し た, 浦の変法（浦, 1956）や中屋の変法（中屋, 1970）に执いて採用されており，イプサティブスコア の制約は無理のないものと思われる。具体的に, 四つ の対象の場合には $\boldsymbol{f}_{-1}=\left(f_{1}, f_{2}, f_{3}\right)^{\prime}$ であり

$$
\boldsymbol{\Lambda}=\left[\begin{array}{rrr}
1 & 0 & 0 \\
0 & 1 & 0 \\
0 & 0 & 1 \\
-1 & -1 & -1
\end{array}\right]
$$

となる。その結果 $\boldsymbol{f}=\left(f_{1}, f_{2}, f_{3},-f_{1}-f_{2}-f_{3}\right)^{\prime}$ と表さ れ，四つの対象に関する喏好度の和が 0 となることが 確認できる。(8)式を(5)式に代入すると

$$
\boldsymbol{x}=\boldsymbol{A} \boldsymbol{\Lambda} \boldsymbol{f}_{-1}+\boldsymbol{e}=\boldsymbol{G} \boldsymbol{f}_{-1}+\boldsymbol{e}
$$

と再表現される。ここで, $\boldsymbol{G}=\boldsymbol{A} \boldsymbol{\Lambda}$ であり, 対象が四 つの場合，以下のように表される。

$$
\boldsymbol{G}=\left[\begin{array}{rrrrrr}
1 & 1 & 2 & 0 & 1 & 1 \\
-1 & 0 & 1 & 1 & 2 & 1 \\
0 & -1 & 1 & -1 & 1 & 2
\end{array}\right]^{\prime}
$$

(10)式をみると, これは新たな計画行列 $\boldsymbol{G}$ を因子負 荷行列とする確認的因子分析モデルであることがわか る。このモデルに扔ける共分散構造を考えると

$$
\boldsymbol{\Sigma}_{x}=\boldsymbol{A} \boldsymbol{\Lambda} \boldsymbol{\Sigma}_{f_{-1}} \boldsymbol{\Lambda}^{\prime} \boldsymbol{A}^{\prime}+\boldsymbol{\Sigma}_{e}=\boldsymbol{G} \boldsymbol{\Sigma}_{f_{-1}} \boldsymbol{G}^{\prime}+\boldsymbol{\Sigma}_{e}
$$

となる。ただし， $\boldsymbol{\Sigma}_{f_{-1}}$ は $\boldsymbol{f}_{-1}$ に関する $(n-1) \times(n-1)$ 共分散行列である。このモデルに関しては, まず因子 分析モデルであるから $\Sigma_{e}$ は識別される。次に $A=$ $\boldsymbol{A}_{-1} \boldsymbol{\Lambda}^{\prime}$ と表すことができる点に注意する。ここで, $\boldsymbol{A}_{-1}$ は $\boldsymbol{A}$ から最後の 1 列を除いた $m \times(n-1)$ の列フ ルランクな行列である。 $\operatorname{rank}\left(\boldsymbol{\Lambda}^{\prime} \boldsymbol{\Lambda}\right)=\operatorname{rank}(\boldsymbol{\Lambda})=n-1$ であるので $\boldsymbol{\Lambda}^{\prime} \boldsymbol{\Lambda}$ は非特異であり, $\operatorname{rank}(\boldsymbol{G})=\operatorname{rank}$ $\left(\boldsymbol{A}_{-1} \boldsymbol{\Lambda}^{\prime} \boldsymbol{\Lambda}\right)=n-1$ となるから $\boldsymbol{G}$ は列フルランクであ り， $\Sigma_{f_{-1}}$ は識別される。続いて平均構造を考えると

$$
\boldsymbol{\mu}_{x}=\boldsymbol{A} \boldsymbol{\Lambda} \boldsymbol{\alpha}_{-1}=\boldsymbol{G} \boldsymbol{\alpha}_{-1}
$$

となり， $\boldsymbol{\alpha}_{-1}$ については制約を入れることなく識別さ れることがわかる。

ここで(6)式と(13)式，(7)式と(12)式とを比較すると $\boldsymbol{\alpha}=$ $\Lambda \alpha_{-1}$ および $\Sigma_{f}=\Lambda \Sigma_{f_{-1}} \Lambda^{\prime}$ が導かれる。したがって， まずは(10)式のモデルに基づいて $n-1$ 個の対象に関す る $\widehat{\boldsymbol{\alpha}}_{-1}, \widehat{\boldsymbol{\Sigma}}_{f_{-1}}$ を得て，そのあとで $\boldsymbol{\Lambda} \widehat{\boldsymbol{\alpha}}_{-1}, \boldsymbol{\Lambda} \widehat{\boldsymbol{\Sigma}}_{f_{-1}} \boldsymbol{\Lambda}^{\prime}$ と変 換することで, $n$ 個の対象についての平均的喏好度, 嗜好度間共分散行列の推定值 $\widehat{\boldsymbol{\alpha}}, \widehat{\boldsymbol{\Sigma}}_{f}$ を得ることが可能 となる。1 段階目の母数推定には, 組み合わせ効果や 順序効果を伴うならば EQS (Bentler \& Wu, 2002) や Mplus（Muthén \& Muthén, 2010)，そうでなければそ れ以外にも Amos (Arbuckle, 2009) や R (Ihaka \& Gentleman, 1996）などの SEM を実行できるソフトウ エアを利用すればよい。また，その後の計算には $\mathrm{R}$ などの行列演算が可能なソフトウェアの利用が考えら れる。

$\boldsymbol{n}$ 番目の対象に関する標準誤差の算出 上述のソフ トウェアの出力から得られる, 推定量の共分散行列の 推定值を利用すると, $n$ 番目の対象の推定值に関する 標準誤差を得ることもできる。平均的喏好度の標準誤 差の計算については, $\widehat{\boldsymbol{\alpha}}=\boldsymbol{\Lambda} \widehat{\boldsymbol{\alpha}}_{-1}$ より, $n$ 番目の対象の 
平均的嗜好度の推定值が $\Lambda$ の $n$ 行目の行ベクトル $-\mathbf{1}^{\prime}{ }_{n-1}$ を用いて $\widehat{\alpha}_{n}=-\mathbf{1}^{\prime}{ }_{n-1} \widehat{\boldsymbol{\alpha}}_{-1}$ と表せることに注目 する。このとき， $\Sigma_{\widehat{\alpha}_{-1}}$ を $\widehat{\boldsymbol{\alpha}}_{-1}$ の共分散行列とすると $\bar{\alpha}_{n}$ の分散は

$$
\sigma_{\bar{\alpha}_{n}}^{2}=\left(-\mathbf{1}^{\prime}{ }_{n-1}\right) \boldsymbol{\Sigma}_{\widehat{\alpha}_{-1}}\left(-\mathbf{1}_{n-1}\right)=\mathbf{1}_{n-1}^{\prime}{ }_{n-1} \boldsymbol{\Sigma}_{\widehat{\alpha}_{-1}} \mathbf{1}_{n-1} \text { (14) }
$$

のように表される。したがって， $\Sigma_{\widehat{\alpha}_{-1}}$ を出力から得ら れる推定值で置き換えて(14)式で計算し，その正の平方 根をとれば $n$ 番目の対象に関する平均的嗜好度の標準 誤差を算出できる。

次に嗜好度間共分散行列に扔ける $n$ 番目の対象に関 連する要素の標準誤差の計算方法について述べる。ま ず，嗜好度間共分散行列の $n$ 行目を $\left(\widehat{\boldsymbol{\Sigma}}_{f}\right)_{n}$. と表すと, $\left(\widehat{\boldsymbol{\Sigma}}_{f}\right)_{n}=-\mathbf{1}_{n-1}^{\prime}\left(\widehat{\boldsymbol{\Sigma}}_{f_{-1}}\right) \boldsymbol{\Lambda}^{\prime}$ が成立し

$$
\operatorname{vec}\left\{\left(\widehat{\boldsymbol{\Sigma}}_{f}\right)_{n} .\right\}=\left\{\boldsymbol{\Lambda} \otimes\left(-\mathbf{1}_{n-1}^{\prime}\right)\right\} \operatorname{vec}\left(\widehat{\boldsymbol{\Sigma}}_{f_{-1}}\right)
$$

となる。ここで, $\operatorname{vec}(\quad)$ は行列の列を 1 番左から順 に下につないでベクトル化する作用素を表し，®はク ロネッカー積の演算子を意味している。そして, この 関係を用いると

$$
\boldsymbol{\Sigma}_{\mathrm{vec}\left(\widehat{\Sigma}_{f}\right)_{n \cdot}}=\left(\boldsymbol{\Lambda} \otimes \mathbf{1}_{n-1}^{\prime}\right) \boldsymbol{\Sigma}_{\mathrm{vec}\left(\widehat{\Sigma}_{f-1}\right)}\left(\boldsymbol{\Lambda} \otimes \mathbf{1}^{\prime}{ }_{n-1}\right)^{\prime}(16)
$$

のようにして嗜好度間共分散行列の $n$ 行べクトル $\left(\widehat{\boldsymbol{\Sigma}}_{f}\right)_{n}$.に関する共分散行列を得られる。ただし,

$\boldsymbol{\Sigma}_{\mathrm{vec}\left(\Sigma_{f-1}\right)}$ は $\operatorname{vec}\left(\widehat{\boldsymbol{\Sigma}}_{f_{-1}}\right)$ の共分散行列である。したがっ て, $\Sigma_{\mathrm{vec}\left(\widehat{\Sigma}_{f-1}\right)}$ の推定值を出力から得て(16)式を計算し, その対角要素の正の平方根をとると標準誤差が算出で きる。

\section{独立成分を導入した一対比較モデルと母数推定}

モデル表現と母数推定 先述の嗜好度間相関推定モ デルを用いると対象の嗜好度間共分散行列を得られ る。そして, 共分散行列が得られたら, それを特徵づ ける要因を探ることでデー夕の背後に存在する構造に ついてさらに知ることが可能となる。ここでは, 先の モデルに独立成分分析を組み込んで，対象の嗜好度間 の関係の背後にある要因について検討する方法を提案 する。

嗜好度間相関推定モデルの $\boldsymbol{f}_{-1}$ に関してさらに

$$
\boldsymbol{f}_{-1}=\boldsymbol{\alpha}_{-1}+\boldsymbol{B}_{-1} \boldsymbol{g}
$$

の構造を考える。独立成分の数を $l$ 個とすると $\boldsymbol{B}_{-1}$ は $(n-1) \times l$ 独立成分負荷行列であり, $l$ 個の独立成分 から $n-1$ 個の対象の嗜好度への影響を表す。また, $\boldsymbol{g}$ は $l \times 1$ 独立成分べクトルである。 $\boldsymbol{g}$ に関しては, $\mathrm{E}[\boldsymbol{g}]=\mathbf{0}$ および, $\boldsymbol{g}$ の要素間の独立性によりその共分 散行列が $\boldsymbol{\Sigma}_{g}=\boldsymbol{I}_{l}$ となることを仮定する。構造方程式モ デリングの観点からは，喏好度間相関推定モデルが測 定方程式であり，(17)式が構造方程式である。独立成分 と $f_{-1}$ との関係は $\boldsymbol{B}_{-1}$ で表現されるが, 独立成分と $\boldsymbol{f}$ との関係にこそ興味がある。そこで

$$
\boldsymbol{f}=\boldsymbol{\Lambda} \boldsymbol{f}_{-1}=\boldsymbol{\Lambda} \boldsymbol{\alpha}_{-1}+\boldsymbol{\Lambda} \boldsymbol{B}_{-1} \boldsymbol{g}
$$

の関係に注目すると, $\widehat{\boldsymbol{B}}_{-1}$ について $\boldsymbol{\Lambda}$ を前から乗じ ることで独立成分と $\boldsymbol{f}$ との関係を表す $n \times l$ 独立成分
負荷行列 $\boldsymbol{B}$ の推定值 $\widehat{\boldsymbol{B}}$ を得られることがわかる。

豊田（2007）は, 3 次の積率を利用した構造方程式 モデリングの枠組みから独立成分分析を行う方法を示 しており，ここではその方法を利用する。(18)式を(5)式 に代入すると，独立成分を導入した一対比較モデルは

$$
\boldsymbol{x}=\boldsymbol{A} \boldsymbol{\Lambda} \alpha_{-1}+\boldsymbol{A} \boldsymbol{\Lambda} \boldsymbol{B}_{-1} g+e
$$

と表現できる。ここで, $\boldsymbol{g}, \boldsymbol{e}$ 間は独立であることを仮 定する。すると原点周りの 1 次の積率構造（平均構 造）と平均周りの 2 次の積率構造 (共分散構造) は

$$
\begin{aligned}
& \mu_{x}=\boldsymbol{A} \boldsymbol{\Lambda} \boldsymbol{\alpha}_{-1} \\
& \boldsymbol{\Sigma}_{x}=\boldsymbol{H} \boldsymbol{H}^{\prime}+\boldsymbol{\Sigma}_{e}
\end{aligned}
$$

となる。ただし, $\boldsymbol{H}=\boldsymbol{A} \boldsymbol{\Lambda} \boldsymbol{B}_{-1}$ であり， $\boldsymbol{\Sigma}_{e}$ は先に定め たものと同様である。また, 平均周りの 3 次の積率構 造は $m^{3} \times 1$ ベクトル形式で

$$
\begin{aligned}
\mathrm{E} & {\left[\left(\boldsymbol{x}-\boldsymbol{\mu}_{x}\right) \otimes\left(\boldsymbol{x}-\boldsymbol{\mu}_{x}\right) \otimes\left(\boldsymbol{x}-\boldsymbol{\mu}_{x}\right)\right] } \\
\quad & =\mathrm{E}[(\boldsymbol{H g}+\boldsymbol{e}) \otimes(\boldsymbol{H g}+\boldsymbol{e}) \otimes(\boldsymbol{H g}+\boldsymbol{e})] \\
& =(\boldsymbol{H} \otimes \boldsymbol{H} \otimes \boldsymbol{H}) \mathrm{E}[\boldsymbol{g} \otimes \boldsymbol{g} \otimes \boldsymbol{g}]+\mathrm{E}[\boldsymbol{e} \otimes \boldsymbol{e} \otimes \boldsymbol{e}]
\end{aligned}
$$

と表される。 $\mathrm{E}[\boldsymbol{g} \otimes \boldsymbol{g} \otimes \boldsymbol{g}]$ と $\mathrm{E}[\boldsymbol{e} \otimes \boldsymbol{e} \otimes \boldsymbol{e}]$ はそれぞれ独 立成分の 3 次母積率ベクトルと誤差の 3 次母積率ベク トルであり, 独立性の仮定から同一変数に関する 3 次 積率, すなわち $\sigma_{g_{i}}^{3}(i=1, \ldots, l)$ と $\sigma_{e j}^{3}(i=1, \ldots,(m-1)$, $j=(i+1), \ldots, m)$ 以外の要素は 0 となる。

そして, 複製行列のムーアペンローズ形逆行列 $D_{p}^{+}$ と 3 重複製行列 (Meijer, 2005)のムーアペンローズ形 逆行列 $T_{p}^{+}$を用いると, 2 次抒よび 3 次の積率構造から 重複要素を除いた積率構造べクトルを $\sigma_{2}=D_{p}^{+} \mathrm{vec}$ $\left(\boldsymbol{\Sigma}_{x}\right), \boldsymbol{\sigma}_{3}=T_{p}^{+} \mathrm{E}\left[\left(\boldsymbol{x}-\mu_{x}\right) \otimes\left(\boldsymbol{x}-\boldsymbol{\mu}_{x}\right) \otimes\left(\boldsymbol{x}-\boldsymbol{\mu}_{x}\right)\right]$ のよう に得ることができる。なお， $\sigma_{2}, \sigma_{3}$ はそれぞれ， $m(m+1) / 2 \times 1, m(m+1)(m+2) / 6 \times 1$ のベクトルで ある。

$\boldsymbol{\sigma}_{1}=\mu_{x}$ とし, $\boldsymbol{\sigma}=\left(\boldsymbol{\sigma}_{1}^{\prime}, \boldsymbol{\sigma}_{2}^{\prime}, \boldsymbol{\sigma}_{3}^{\prime}\right)^{\prime}$ によって1 次から 3 次までの重複のない積率構造べクトルを作り, $\boldsymbol{\sigma}$ に 対応する標本積率べクトルを $s=\left(s_{1}^{\prime}, s_{2}^{\prime}, s_{3}^{\prime}\right)^{\prime}$ と表す と

$$
f_{\mathrm{ADF} 3}=(\boldsymbol{s}-\boldsymbol{\sigma})^{\prime} \boldsymbol{W}^{-1}(\boldsymbol{s}-\boldsymbol{\sigma})
$$

のように目的関数を構成することができる。Wは $s$ の漸近共分散行列の一致推定量を標本サイズ倍したも のであり, $f_{\mathrm{ADF} 3}$ を最小化することによってモデル母 数の ADF3 推定值（Mooijaart, 1985）を得る。

本モデルでは， $\widehat{\boldsymbol{\alpha}}_{-1}, \widehat{\boldsymbol{B}}_{-1}$ を用いて, $\widehat{\boldsymbol{\alpha}}=\boldsymbol{\Lambda} \widehat{\boldsymbol{\alpha}}_{-1}, \widehat{\boldsymbol{B}}=$ $\boldsymbol{\Lambda} \widehat{\boldsymbol{B}}_{-1}, \widehat{\boldsymbol{\Sigma}}_{f}=\boldsymbol{\Lambda} \widehat{\boldsymbol{B}}_{-1} \widehat{\boldsymbol{B}}^{\prime}{ }_{-1} \boldsymbol{\Lambda}^{\prime}$ とすることで, $\boldsymbol{f}$ に関する平 均的嗜好度, 独立成分負荷行列, 嗜好度間共分散行列 の推定值を求められる。また, $\widehat{\boldsymbol{D}}_{f}^{-1 / 2} \widehat{\boldsymbol{\Sigma}}_{f} \widehat{\boldsymbol{D}}_{f}^{-1 / 2}$ によっ て嗜好度間相関行列の推定值を得たり， $\widehat{\boldsymbol{D}}_{f}^{-1 / 2} \widehat{\boldsymbol{B}}$ を計 算して標準化された独立成分負荷行列を得ることもで きる。ここで, $\boldsymbol{D}_{f}=\operatorname{Diag}\left(\boldsymbol{\Sigma}_{f}\right)$ であり, $\operatorname{Diag}(\quad)$ は 括弧内の正方行列の非対角要素を 0 とした対角行列を 生成する作用素を意味する。

$\boldsymbol{n}$ 番目の対象に関する標準誤差の算出 $\alpha_{n}$ の標準誤 差は嘹好度間相関推定モデルの場合と同様に算出でき 
る。ここでは $\widehat{\boldsymbol{B}}$ の $n$ 行目である $(\widehat{\boldsymbol{B}})_{n}$. の標準誤差を 求める方法を述べる。 $(\widehat{B})_{n} .=-\mathbf{1}^{\prime}{ }_{n-1} \widehat{\boldsymbol{B}}_{-1}$ の等式に関 して vec 作用素を適用すると $\operatorname{vec}\left\{(\widehat{\boldsymbol{B}})_{\mathrm{n}} \cdot\right\}=\left\{\boldsymbol{I}_{l} \otimes\left(-\mathbf{1}_{n-1}^{\prime}\right)\right\} \operatorname{vec}\left(\widehat{\boldsymbol{B}}_{-1}\right) \quad$ (26) となる。これを用いると $\operatorname{vec}\left\{(\widehat{\boldsymbol{B}})_{n}.\right\}$ の共分散行列は $\boldsymbol{\Sigma}_{\mathrm{vec}\left\{\left(\widehat{\boldsymbol{B}}_{n},\right\}\right.}=\left(\boldsymbol{I}_{l} \otimes \mathbf{1}^{\prime}{ }_{n-1}\right) \boldsymbol{\Sigma}_{\mathrm{vec}\left(\widehat{\boldsymbol{B}}_{-1}\right)}\left(\boldsymbol{I}_{l} \otimes \mathbf{1}^{\prime}{ }_{n-1}\right)^{\prime} \quad(27)$ と表される。出力結果から得られる, $\operatorname{vec}\left(\widehat{\boldsymbol{B}}_{-1}\right)$ につ いての共分散行列 $\boldsymbol{\Sigma}_{\mathrm{vec}\left(\widehat{\boldsymbol{B}}_{-1}\right)}$ の推定值を(27)式に代入し て計算し, その対角要素の正の平方根を求めれば $n$ 番 目の対象に関する独立成分負荷量の標準誤差を得られ る。

\section{調査}

提案モデルの適用例として質問紙調査データの分析 結果を示す。調査では緑茶飲料, シャンプーの二つの 商品を取り上げた。そしてそれぞれについて新製品の 売り出し場面を想定して複数のネーミングを考え, そ の好みを一対比較により評価することを調査参加者に 求めた。

\section{方 法}

質問紙 二つの商品それぞれについて，六つのネー ミング候補を用意し，各ネーミングのコンセプトおよ び由来を調査参加者に説明したのち, 判断の往復を許 した 15 個の比較対に回答を求めた。比較対は左右に ネーミングを配置する形で提示し，回答形式は “左の ネーミングが非常に好き (3)”から“どちらでもない (0)”を経由して“右のネーミングが非常に好き $(-3)$ ”とする 7 件法とした。15 個の比較対におい て, 左右のどちらかに偏って多く出現するネーミング がないように注意するとともに，比較対自体の提示順 にも配虑した。

調査参加者 調査参加者は緑茶飲料, シャンプーに 関して 166 名, 158 名であり, 同数の有効回答を得 た。

分析 質問紙の回収後, 比較対の提示順序と位置が 適切になるように值の変換や列の置換を施してデー夕 行列を準備した。そして, 今回の分析では各商品につ き，六つのネーミングのうち四つのみを扱うこととし て，それらに関する六つの比較対のデー夕を取り出し て分析対象とした。本適用例では $\mathrm{R}$ を用いて, $f_{-1}$ の 要素間の無相関を仮定して表現される嗜好度間無相関 モデルと独立成分を導入した一対比較モデルによって 分析を行った ${ }^{4}$ 。基となる一対比較モデルにおいて組 み合わせ効果と順序効果の項は扱わなかった。独立成 分の数が 0 個から 5 個までの場合で分析し，独立成分 0 個のモデルの推定の初期值には Mplusによる嗜好度

\footnotetext{
4 分析に使用されたスクリプトに関するお問い合わせは第一 著者e-mail アドレスまで。
}

Table 1

緑茶飲料データに関する適合度の要約

\begin{tabular}{lrrrrr}
\hline 成分数 & $d f$ & \multicolumn{1}{c}{$\chi^{2}$ 値 } & RMSEA & \multicolumn{1}{c}{ AIC } & \multicolumn{1}{c}{ BIC } \\
\hline 無相関 & 62 & 267.257 & .141 & 143.257 & -49.686 \\
0 & 52 & 85.861 & .062 & -18.139 & -179.962 \\
1 & 64 & 284.237 & .144 & 156.237 & -42.930 \\
2 & 60 & 174.973 & .107 & 54.973 & -131.746 \\
3 & 56 & 116.087 & .080 & 4.087 & -170.184 \\
4 & - & - & - & - & - \\
5 & - & - & - & - & - \\
\hline
\end{tabular}

間相関推定モデルの推定值を，独立成分 1 個以上のモ デルの推定の初期值には独立成分 0 個のモデルの推定 值を利用した。

\section{結果と解䣋}

緑茶飲料のネーミング ネーミング候補は(a)滅茶哉 培 (めちゃヤバイ), (b)茶, destination, (c)粗茶です が…, (d)飲め!の四つであり, 対象に対する嗜好度の 確率変数が順に $f_{1}, f_{2}, f_{3}, f_{4}$ で表される。緑茶飲料の ネーミングデータの分析における適合度を Table 1 に まとめた。Table 1 から AIC や BIC を確認すると緑 茶飲料デー夕に関しては独立成分 0 個のモデルのあて はまりが一番良いことがわかる。また RMSEA は .062であり, 当該モデルの適合が比較的良好である ことを示している。なお，独立成分 4 個，5個のモデ ルは不適解であった。

$\boldsymbol{f}_{-1}$ に関する平均的嗜好度と嗜好度間共分散行列の 推定值を Table 2 に示した。一番左の列の $\boldsymbol{\Sigma}_{f_{-1}(i, j)}$ $(i=j, \ldots, 3, j=1, \ldots, 3)$ は $\Sigma_{f-1}$ の $(i, j)$ 要素を表し ている。 $\widehat{\boldsymbol{\alpha}}_{-1}$ を用いると $\widehat{\boldsymbol{\alpha}}=(-.020,-.392, .554$, $-.142)^{\prime}$ と計算され, 各推定值の標準誤差は.037, $.039, .040, .041$ であった。また, 嗜好度間共分散行列 $\boldsymbol{\Sigma}_{f}$ と嗜好度間相関行列 $\boldsymbol{R}_{f}$ の推定值は以下のように算 出された。 $\widehat{\boldsymbol{\Sigma}}_{f}$ の 4 行目に関する標準誤差は.038, .035, .036, .040であった。

$$
\begin{gathered}
\widehat{\boldsymbol{\Sigma}}_{f}=\left[\begin{array}{rrrr}
.523 & -.258 & -.231 & -.034 \\
-.258 & .475 & -.037 & -.180 \\
-.231 & -.037 & .500 & -.232 \\
-.034 & -.180 & -.232 & .446
\end{array}\right] \\
\widehat{\boldsymbol{R}}_{f}=\left[\begin{array}{rrrr}
1.000 & -.518 & -.451 & -.070 \\
-.518 & 1.000 & -.076 & -.391 \\
-.451 & -.076 & 1.000 & -.492 \\
-.070 & -.391 & -.492 & 1.000
\end{array}\right]
\end{gathered}
$$

推定值の解釈をすると, 平均的喏好度は “粗茶です が...”が最も高く, 大きく離れて“滅茶哉培（めちゃ ヤバイ), “飲め!”, そして最後に“茶, destina- 
Table 2

緑茶飲料データに関する $\boldsymbol{\alpha}_{-1}$ と $\boldsymbol{\Sigma}_{f_{-1}}$ の推定值

\begin{tabular}{lrcr}
\hline \multicolumn{1}{c}{ 母数 } & 推定值 & 標準誤差 & \multicolumn{1}{c}{$z$ 值 } \\
\hline$\alpha_{1}$ & -.020 & .037 & -0.530 \\
$\alpha_{2}$ & -.392 & .039 & -10.105 \\
$\alpha_{3}$ & .554 & .040 & 14.018 \\
$\Sigma_{f_{-1}(1,1)}$ & .523 & .044 & 12.016 \\
$\Sigma_{f_{-1}}(2,1)$ & -.258 & .035 & -7.379 \\
$\Sigma_{f_{-1}(3,1)}$ & -.231 & .036 & -6.394 \\
$\Sigma_{f_{-1}(2,2)}$ & .475 & .047 & 10.080 \\
$\Sigma_{f_{-1}(3,2)}$ & -.037 & .032 & -1.146 \\
$\Sigma_{f_{-1}(3,3)}$ & .500 & .046 & 10.933 \\
\hline
\end{tabular}

tion”の順であった。ただし，標準誤差を利用して， 推定值 $\pm 1.96 \times$ 標準誤差によって $95 \%$ 信頼区間を計 算すると， $\alpha_{1}$ の信頼区間が $(-.093, .053), \alpha_{4}$ の信頼 区間が $(-.223,-.060)$ となるから“滅茶哉培（め ちゃヤバイ)”と“飲め!”の平均的嗜好度の間には 統計的な差があるとはいえないことになる。また，個 人差の分散については信頼区間の点から四つの対象の 間に差があるとはいえない。

嗜好度間相関行列に関しては “滅茶哉培（めちゃヤ バイ)”と“飲め!”, “茶, destination”と“粗茶で すが...”の間には相関が認められなかったが，それ以 外の部分に中程度の相関があった。最も相関が強いの は“滅茶哉培（めちゃヤバイ）”と“茶, destination” の間で，推定值は一. .518 であった。“滅茶哉培（めち やヤバイ)”は“粗茶ですが...”との間にも-.451の 負の相関があり，“滅茶哉培（めちゃヤバイ）”を好む 人は“茶, destination”や“粗茶ですが...”をあまり 好まない傾向があることがわかる。

シャンプーのネーミング 四つのネーミング候補は (a)雅（みやび)，(b)クレオパトラ, (c)ルミネール, (d) 美髪推進委員会, である。シャンプーのネーミングデ 一夕の分析に扔ける適合度を Table 3 に示した。

Table 3 を検討すると, AIC, BIC の点から独立成分 が 3 個のモデルが最適なモデルとして選択され,

RMSEA の值から許容できるレベルであることが認 められる。適合度の点から最適モデルとはされなかっ たが，独立成分が 4 個のモデルも推定された。独立成 分を考慮しなければ，このモデルは 3 因子の因子分析 モデルであり， 1 次因子の数よりも多い 4 個の独立成 分を抽出できることが示された。独立成分 5 個のモデ ルについては, 緑茶飲料デー夕に続き不適解であっ た。さらに, 緑茶飲料デー夕の分析と同様, 成分数 1 個の場合の適合度が最も悪いこともわかる。独立成分 と嗜好度の関係においては誤差が仮定されていないの で, 独立成分一つだけの情報では嗜好度間の共分散や 3 次積率を近似するのが難しく, 今回の二つのデー夕 に関してはそれがあてはまりの悪さに繋がったと推測
Table 3

シャンプーデータに関する適合度の要約

\begin{tabular}{lcccrr}
\hline 成分数 & $d f$ & $\chi^{2}$ 值 & RMSEA & \multicolumn{1}{c}{ AIC } & \multicolumn{1}{c}{ BIC } \\
\hline 無相関 & 62 & 223.551 & .128 & 99.551 & -90.330 \\
0 & 52 & 124.082 & .093 & 20.082 & -139.173 \\
1 & 64 & 308.990 & .156 & 180.990 & -15.016 \\
2 & 60 & 201.748 & .122 & 81.748 & -102.008 \\
3 & 56 & 130.143 & .091 & 18.143 & -153.362 \\
4 & 52 & 124.082 & .093 & 20.082 & -139.173 \\
5 & - & - & - & - & - \\
\hline
\end{tabular}

Table 4

シャンプーデータに関する $\boldsymbol{\alpha}_{-1}$ と $\boldsymbol{B}_{-1}$ の推定值

\begin{tabular}{lrcr}
\hline \multicolumn{1}{c}{ 母数 } & 推定值 & 標準誤差 & \multicolumn{1}{c}{$z$ 值 } \\
\hline$\alpha_{1}$ & .528 & .033 & 15.916 \\
$\alpha_{2}$ & -.050 & .029 & -1.758 \\
$\alpha_{3}$ & .195 & .035 & 5.561 \\
$\boldsymbol{B}_{-1(1,1)}$ & -.316 & .051 & -6.205 \\
$\boldsymbol{B}_{-1(2,1)}$ & -.167 & .036 & -4.642 \\
$\boldsymbol{B}_{-1(3,1)}$ & -.213 & .054 & -3.924 \\
$\boldsymbol{B}_{-1(1,2)}$ & -.117 & .063 & -1.855 \\
$\boldsymbol{B}_{-1(2,2)}$ & .464 & .036 & 13.042 \\
$\boldsymbol{B}_{-1(3,2)}$ & -.242 & .057 & -4.280 \\
$\boldsymbol{B}_{-1(1,3)}$ & .478 & .044 & 10.820 \\
$\boldsymbol{B}_{-1(2,3)}$ & -.126 & .049 & -2.546 \\
$\boldsymbol{B}_{-1(3,3)}$ & -.521 & .037 & -13.984 \\
\hline
\end{tabular}

される。

独立成分三つのモデルについて，四つの対象のうち 最後の一つを除いた三つに関する平均的嗜好度と独立 成分負荷量の推定值を Table 4 として揭載した。 Table 4 の最も左の列の $\boldsymbol{B}_{-1(i, j)}(i=1, \ldots, 3, j=1$, $\ldots, 3)$ は $\boldsymbol{B}_{-1}$ の $(i, j)$ 要素を表している。なお，独 立成分と誤差に関する 2 次と 3 次の積率の推定値も適 切な值で推定されたが, 紙面の都合上割愛した。推定 值を利用して四つの対象に関する平均的嗜好度は $\widehat{\boldsymbol{\alpha}}=(.528,-.050, .195,-.672)^{\prime}$, 標準誤差は.033, $.029, .035, .038$ と算出された。また，嗜好度の個人差 の分散推定值は順に, $.335, .255, .396, .548$ であった。 そして, 四つの対象に関する独立成分負荷行列 $\widehat{\boldsymbol{B}}$ と 標準化された独立成分負荷行列 $\widehat{\boldsymbol{B}}_{\mathrm{st}}$ は以下のように求 められ， $\widehat{\boldsymbol{B}}$ の 4 行目の推定值の標準誤差はそれぞれ， $.035, .043, .055$ となった。

$$
\widehat{\boldsymbol{B}}=\left[\begin{array}{rrr}
-.316 & -.117 & .478 \\
-.167 & .464 & -.126 \\
-.213 & -.242 & -.521 \\
.696 & -.104 & .169
\end{array}\right]
$$




$$
\widehat{\boldsymbol{B}}_{\mathrm{st}}=\left[\begin{array}{rrr}
-.540 & -.200 & .817 \\
-.329 & .911 & -.247 \\
-.348 & -.395 & -.850 \\
.962 & -.144 & .234
\end{array}\right]
$$

平均的嗜好度については, “雅（みやび)”が四つの 対象の中で突出して高く, “ルミネール”, 少し離れて “クレオパトラ” と続き, “美髪推進委員会” は“クレ オパトラ”と比べてもかなり低かった。四つの対象に 関する 95\%信頼区間は重複しておらず, 平均的嗜好 度の点から明確な順位付けが可能であった。嗜好度の 個人差のばらつきの点からみると, “クレオパトラ” が最も小さく, 調査参加者間で嗜好の違いが出にくい ネーミングであったことがわかった。反対に“美髪推 進委員会” は分散が大きいので, 個人によって嗜好の 程度が異なり易いネーミングであったといえる。

独立成分負荷行列に関しては, 值の比較が可能な $\widehat{\boldsymbol{B}}_{\mathrm{st}}$ の解釈を行う。第 1 成分は “美髪推進委員会” の みに非常に強い正の影響を与えており，その他のネー ミングには中程度の負の影響を与えていることが認め られる。この成分は，漢字が羅列されたネーミングに 対する印象の良さを表す“漢字羅列”成分と解釈でき る。英語表記の多いシャンプーの製品名の中で漢字が 並んだネーミングに対して好感をもつ人は“美髪推進 委員会”に対する嗜好が強くなると推測される。次 に，第 2 成分は“クレオパトラ”に強い正の影響を与 えている。“クレオパトラ”という響きからはエジプ ト女王のきらびやかなイメージが明確に浮かぶ。この 独立成分は高貴な人物のイメージを抱かせるネーミン グに対する印象の良さを表す“高貴な人物”成分であ ると考えられる。“クレオパトラ”以外のネーミング は，高貴な人物というイメージとの結びつきがあまり 強くなく，この成分からの影響の強さもあまり大きく ない。最後に，第 3 成分は“雅（みやび)”に対して 強い正の影響を与え, “ルミネール”には強い負の影 響を与えている。また, この成分は“美髪推進委員 会”にも正の影響を与えていることから，日本的な美 しい髪のイメージを抱かせるネーミングに対する印象 の良さを表す“日本的美髪”成分であると推測でき る。“雅（みやび）” は平安時代の上品な女性の美しく 長い黒髪のイメージを, “美髪推進委員会” は髪に対 するよい効果を与えることによる美しい髪のイメージ やテレビコマーシャルとして放送されていそうなイメ ージを喚起させ，それがそれぞれのネーミングに対す る嗜好に繋がっているものと考えられる。一方, “ル ミネール” は西洋的なイメージを表面上与えるととも に，意味的にも美しい髪のイメージとも結びつきにく いネーミングであり，日本的な美しい髪に好印象を抱 く人からは好まれにくいのだと思われる。

\section{考察}

本論文では, 多重評価状況におけるシェッフェ型一 対比較モデルにおいて, 対象に対する嗜好度間の相関 を検討する方法を提案した。一つ目の嗜好度間相関推 定モデルは, 最後の一つの対象の嗜好度を除いた $n-1$ 個の因子を仮定し, 従来の方法で用いられたものと異 なった計画行列をもつ因子分析モデルととらえること ができた。モデルとしては単純であり，分析にはこれ まで共分散構造分析用に開発された多くのソフトウェ アを利用できる。提案モデルの説明の中でも触れたよ うに，本論文で導入された嗜好度に関するイプサティ ブスコアの仮定は, 伝統的な一対比較手法において用 いられたものと同等であり，嗜好度間相関推定モデル はそれらの手法をSEM の枠組みから表現したモデル と考えられる。しかしながら，本手法の主眼がこれま での方法では難しかった各対象に対する個人の嗜好度 間の相関を推定し検討することにある点で異なってい る。また, 各種推定值に関する標準誤差や適合度指標 など, 分析から得られる情報は本手法の方がかなり豊 富である。組み合わせ効果, 順序効果の導入や誤差分 散の等分散性の仮定の導入，またそれらの仮定に関す る適切性の評価などもできる点は伝統的な手法と比較 して本手法が秀でている点である。

独立成分を導入した一対比較モデルは，嗜好度間相 関推定モデルの因子にさらに構造を組み込んだモデル として表現された。適用例からは,このモデルを用い て各対象への嗜好の背後に存在する要素を見つけだせ る可能性が示された。SEMの枠組みを利用すること で，適合度指標を参照して独立成分の数を決定するこ とが可能となり，さらにはすべての対象に関して平均 的嗜好度と独立成分負荷量の推定值および, 標準誤差 をも得ることができた。これにより，従来の手法での 視点に加えて, 対象に対する嗜好が何個のどのような 性質をもった成分から成り立っているのかという，新 たな視点からの考察も可能となる。なお, 3 次積率の 利用は歪みの情報の利用を意味しており, シェッフェ やサーストンの伝統的な一対比較法において仮定され ていた嗜好度に関する正規性の仮定を和らげることを 意味している。Scheffé（1952）にも述べられていた ように正規性の仮定については満たされないことも多 く，現実場面に即した分析方法と考えることもできる かもしれない。

最後に, 今後の課題および留意事項として三つの点 を挙げる。まず，独立成分を導入した一対比較モデル は変数の歪みの大きさを推定に利用しているため, 変 数の歪みの大きさにより母数の推定精度が異なってく る可能性がある。解釈において重要となる独立成分負 荷行列, 平均的嗜好度やそれらの標準誤差に特に注目 してその点について検討することが今後必要になると 
考えられる。次に，独立成分を導入した一対比較モデ ルはそれほど複雑なものではないが, 3 次の積率を利 用するので，ある程度の標本サイズの大きさが必要と なる。今回の分析例では対象が四つで評価者が 160 名 程度であったが，対象が多くなるとより多くの評価者 が必要となることが推測される。そして最後に，今回 の二つの手法では対象のうち最後の一つを除いてモデ ル表現を行ったが，除く対象は任意で構わない。モデ ルが単純であり，一般的には推定值に大きな影響を与 えることは考えにくいものの適合度があまり良くない などの理由により，除く対象によって推定に影響が出 る可能性もあることは気に留めておかなくてはならな い。

\section{引用文献}

Arbuckle, J. L. (2009). Amos 18 user's guide. Craw Fordville, FL: Amos Development Corporation.

Arbuckle, J. L., \& Nugent, J. H. (1973). A general procedure for parameter estimation for the law of comparative judgment. British Journal of Mathematical and Statistical Psychology, 26, 240-260.

Bentler，P. M., \& Wu， E. J.C. (2002). EQS6 for Windows user's guide. Encino, CA: Multivariate Software, Inc.

Ihaka, R., \& Gentleman, R. (1996). A language for data analysis and graphics. Journal of Computational and Graphical Statistics, 5, 299-314.

Meijer, E. (2005). Matrix algebra for higher order moments. Linear Algebra and its Applications, 410, 112-134.

Mooijaart, A. (1985). Factor analysis for non-normal variables. Psychometrika, 50, 323-342.

Muthén, L. K., \& Muthén, B. O. (2010). Mplus user's guide. 6th ed. Los Angeles, CA: Muthén \& Muthén.

中屋澄子 (1970). Scheffé の一対比較法の一変法 第 11 回日本科学技術連盟官能検查大会報文集, 1-12.

(Nakaya, S.)

野澤昌弘・飯田一郎・椿広計・芳賀 敏郎・鎗田
政男・吉澤 正（1995）。一対比較デー夕における 個人差の解析法について 品質, 25, 81-89.

(Nozawa, M., Iida, I., Tsubaki, H., Haga, T., Yarita, M., \& Yoshizawa, T. (1995). A method for evaluating individual variation in paired comparison data. Quality, 25, 81-89.)

佐藤 信 (1985)。統計的官能検查法 日科技連出版社 (Sato, S.)

Scheffé, H. (1952). An analysis of variance for paired comparisons. Journal of American Statistical Association, 47, 381-400.

豊田 秀樹（2007）。共分散構造分析（理論編）——構 造方程式モデリング—— 朝倉書店

(Toyoda, H.)

豊田秀樹 - 室橋弘人・尾崎幸謙・芳賀麻誉美 (2004)．実験デザインに基づく一対比較データの 解析一一構造方程式モデリングによる表現— 心理学研究, 75, 33-40.

(Toyoda, H., Murohashi, H., Ozaki, K., \& Haga, M. (2004). Analysis of paired comparison data based on experimental design: Expression using structural equation modeling. Japanese Journal of Psychology, 75, 33-40.)

豊田秀樹・尾崎幸謙・室橋弘人・芳賀麻誉美 (2004)。構造方程式モデリングによる一対比較法 の分析—シェッフェの方法とその改良—— 心 理学研究, 75, 299-307.

(Toyoda, H., Ozaki, K., Murohashi, H., \& Haga, M. (2004). Paired comparison analysis by using structural equation modeling: Scheffe's method and its improvements. Japanese Journal of Psychology, 75, 299-307.)

Tsai, R. C. (2000). Remarks on the identifiablity of thurstonian ranking models: $\mathrm{CaseV}$, caseIII, or neither? Psychometrika, 65, 233-240.

Tsai, R. C. (2003). Remarks on the identifiablity of thurstonian paired comparison models under multiple judgment. Psychometrika, 68, 361-372.

浦 昭二 (1956)。一対比較実験の解析 日本科学技術 連盟官能検査研究会資料, 1-8.

(Ura, S.)

2010. 11. 26 受稿, 2011.7.2 受理—— 